\title{
LONG-TERM PREDICTIVE ABILITY OF BANKRUPTCY MODELS IN THE CZECH REPUBLIC: EVIDENCE FROM 2007-2012
}

\author{
Machek, 0.
}

Bankruptcy models are a common tool of financial analysis to predict the financial distress of companies. However, in the recent years, the instability and risk of the overall economic environment have underlined the need for accurate tools to predict bankruptcy and assess the overall performance of companies. In this article, we analyze the ex-ante predictive ability of selected bankruptcy and solvency models commonly used in financial analysis: Kralicek quick test, Taffler model, the IN99 and IN05 indexes, and Altman Z'-score models in the case of Czech companies from 2007 to 2012. We determined the percentage of cases when these models correctly predicted failures of companies up to five years in advance, and found that the IN05 and IN99 credibility indexes provided the best results, as well as the Altman Z'-score model. However, the predictive ability of the Taffler model and Kralicek quicktest has only been limited.

JEL classification: G30, G33

Keywords: bankruptcy prediction; Altman Z'-score; Taffler model; Kralicek quick test; IN05; IN99

\section{Introduction}

The number of bankruptcies in the Czech Republic has kept growing since the introduction of the new insolvency law in 2008, which concerns, in particular, small businesses and individual entrepreneurs. The yields of creditors in insolvency proceedings have reached very low values (see Smrčka and Schönfeld, 2014 for a more detailed discussion). Companies may deal with a crisis by various measures, for instance, reassessment of investments, reduction of personnel costs or strengthening of cash flow (see e.g. Krause, 2013) or reappraisal of outsourcing activities (see e.g. Tyll, 2011). Nevertheless, a timely recognition of a company's crisis could reduce the harmful effects of company failures on individuals as well as on legal persons. In recent years, the instability of the economic environment underlined the need for accurate tools to predict bankruptcy and assess overall performance of companies. In this article, we test the predictive ability of selected bankruptcy and solvency models commonly used in financial analysis: the Kralicek quick test, Taffler model, the IN05 and IN99 credibility indexes, and Altman Z'-score models in the Czech environment. The article tests whether these models had a real ex ante predictive ability using the data on Czech companies with more than 10 employees in the 2007-2012 period.

\section{Bankruptcy and Solvency Models}

A number of models to detect financial distress have been developed in the past. Despite the variety of models available, business practitioners and researchers often rely on the most popular models, among which we can cite the Altman Z-score (Altman, 1968), Kralicek quick test (Kralicek, 1991), Taffler model (Taffler and Tisshaw, 1977) and in the Czech environment, the indexes of credibility (see, for instance, Neumaierová and Neumairer, 2014). The popularity of these models is due to the fact that they have a simple mechanism of calculation and an intuitive and clear way of interpreting the results.

Many authors have tested the predictive ability of bankruptcy models in particular conditions in the past. For instance, Collins (1980) compared the Altman Z-score against more sophisticated ways of bankruptcy prediction and confirmed that the Altman's model performed well enough. Some authors consider the Altman model to be able to predict financial distress 2-3 years in advance. More recently, Wang and Campbell (2010) examined the ability of Z-score models in China, and Agarwal and Taffler (2007) tested the predictive ability of the Taffler Z-score model on UK-based data and affirmed that the model had a good predictive ability. Concerning the Czech environment, the limits of bankruptcy models have been examined by many authors. Čámská (2012) 
described bankruptcy prediction models which were created during the nineties in Central and Eastern Europe. Perhaps the most comprehensive research on the efficiency of bankruptcy models in the Czech environment (before the global economic crisis in 2008) was done by Maňasová (2007) who concluded that the IN indexes performed well and the Altman's Z-score models had the best predictive ability in selected industries.

\section{Altman Z'-Score model}

Perhaps the most famous model is the Altman Z-Score which was originally published in 1968 (Altman, 1968) and further modified to better reflect particular operating conditions. The model is based on discriminate analysis. The Altman Z'-score for private firms can be specified as:

$$
\begin{gathered}
Z^{\prime}=0.717^{\prime} T_{1}+0.847^{\prime} T_{2}+3.107^{\prime} T_{3}+0.420^{\prime} T_{4}+ \\
+0.998^{\prime} T_{5}
\end{gathered}
$$

where $T_{1}$ is the ratio of net working capital (current assets less current liabilities) over total assets, $T_{2}$ is the ratio of retained earnings over total assets, $T_{3}$ is the ratio of earnings before interest and taxes (EBIT) over total assets, $T_{4}$ is the ratio of equity over total liabilities and $T_{5}$ is the asset turnover (sales over total assets). According to the resulting value of the Z'-score, companies can be classified into the following groups:

Table 1 Zones of discrimination according to Altman Z'-score

\begin{tabular}{|c|c|}
\hline Value of $Z^{\prime}$ & Zone of discrimination \\
\hline$Z>2.9$ & Safe zone \\
\hline $1.23<Z<2.9$ & Grey zone \\
\hline$Z<1.23$ & Financial distress zone \\
\hline
\end{tabular}

\section{Kralicek Quick Test}

The quick test developed by Kralicek (1991) which was further modified in 1999 is an example of "solvency models" and evaluates the company's financial and revenue position.
It takes into account multiple financial ratios and assigns the following scores according to the resulting values (table 2).

The following aspects of a company's position are then evaluated:

- Financial stability: $\left(X_{1}+X_{2}\right) / 2$

- Revenue position: $\left(X_{3}+X_{4}\right) / 2$

- Overall position: (Financial stability + Revenue position) / 2

Table 3 Kralicek quick test score

\begin{tabular}{|c|c|}
\hline Score & Position \\
\hline 4 & Very good company \\
\hline 3 & Good company \\
\hline 2 & Average company \\
\hline 1 & Weak company \\
\hline 0 & Very weak company \\
\hline
\end{tabular}

\section{Taffler Model}

The Taffler model developed by Taffler and Tisshaw (1997) is based on calculating the following score:

$$
Z=0.53^{\prime} T_{1}+0.13^{\prime} T_{2}+0.18^{\prime} T_{3}+0.16^{\prime} T_{4}
$$

where $T_{1}$ denotes earnings before taxes (EBT) over short-term liabilities, $T_{2}$ denotes current assets over total liabilities, $T_{3}$ denotes short-term liabilities over total assets and $T_{4}$ denotes the asset turnover (sales over assets). According to the resulting value of the final score, companies can be classified into the following groups:

\section{Table $4 \mathrm{Z}$ ones of discrimination according to Taffler} model

\begin{tabular}{|c|c|}
\hline Value of $Z$ & Position \\
\hline$Z>0.3$ & $\begin{array}{r}\text { Companies with a lower probability } \\
\text { of bankruptcy }\end{array}$ \\
\hline$Z<0.2$ & $\begin{array}{r}\text { Companies with a higher probability } \\
\text { of bankruptcy }\end{array}$ \\
\hline
\end{tabular}

Table 2 Kralicek quick test

\begin{tabular}{|c|l|c|c|c|c|c|}
\hline \multirow{2}{*}{ Indicator } & \multicolumn{5}{c|}{ Points } \\
\cline { 2 - 7 } & $\mathbf{0}$ & $\mathbf{1}$ & $\mathbf{2}$ & $\mathbf{3}$ & $\mathbf{4}$ \\
\hline$X_{1}$ & Assets / Equity & $X_{1}>0.8$ & $0.8>X_{1}>0.6$ & $0.6>X_{1}>0.4$ & $0.4>X_{1}>0.2$ & $0.2>X_{1}>0$ \\
\hline$X_{2}$ & (Liabilities + loans) / Operating cash-flow & $X_{2}>0.8$ & $0.8>X_{2}>0.6$ & $0.6>X_{2}>0.4$ & $0.4>X_{2}>0.2$ & $0.2>X_{2}>0$ \\
\hline$X_{3}$ & EBIT / Assets & $X_{3}>0.8$ & $0.8>X_{3}>0.6$ & $0.6>X_{3}>0.4$ & $0.4>X_{3}>0.2$ & $0.2>X_{3}>0$ \\
\hline$X_{4}$ & Operating cash-flow / Sales & $X_{4}>0.8$ & $0.8>X_{4}>0.6$ & $0.6>X_{4}>0.4$ & $0.4>X_{4}>0.2$ & $0.2>X_{4}>0$ \\
\hline
\end{tabular}

Note: $X$ denotes the value of the indicator in the row 


\section{Credibility Indexes: IN99 and IN05}

IN99 and IN05 belong to the class of indices of credibility developed by Neumaierová and Neumaier (for a detailed description, see e.g. Neumaierová and Neumaier, 2014). While IN99 reflects the owner's situation, a more recent version IN05 reflects the point of view of creditors as well as owners. The resulting value of the index provides a statement whether a company creates value for shareholders or not.

IN99 can be calculated as:

IN99 $=-0.017^{\prime} T_{1}+4.573^{\prime} T_{2}+0.481^{\prime} T_{3}+0.015^{\prime} T_{4}$

where $T_{1}$ denotes assets over liabilities, $T_{2}$ denotes EBIT over assets, $T_{3}$ denotes revenue over assets and $T_{4}$ is the ratio of current assets over the sum of short-term liabilities and short-term bank loans.

IN05 can be calculated as:

$I N 05=0.13^{\prime} T_{1}+0.04^{\prime} T_{2}+3.97^{\prime} T_{3}+0.21^{\prime} T_{4}+0.09^{\prime} T_{5}$

where $T_{1}$ denotes assets over liabilities, $T_{2}$ denotes EBIT over interests, $T_{3}$ denotes EBIT over assets, $T_{4}$ denotes revenue over assets and $T_{5}$ is the ratio of current assets over short-term liabilities.

According to the value of the final score, companies can be classified into the following groups:

Table 5 Classification of companies according to IN99 and IN05

\begin{tabular}{|c|c|c|}
\hline IN99 & IN05 & Position \\
\hline IN99 $>2.07$ & IN05 $>1.6$ & Healthy situation \\
\hline $2.07>$ IN99 $>0.684$ & $1.6>$ IN05 $>0.9$ & Grey zone \\
\hline IN99 $<0.648$ & IN05 $<0.9$ & Unhealthy situation \\
\hline
\end{tabular}

\section{Data and Methodology}

We used the Albertina database maintained by the Bisnode company. This database contains financial data about all subjects with a registered ID in the Czech Republic. We focused on companies with more than 10 employees in the 2007-2012 period (8 924 companies with a unique ID). The research was based on an observation whether the models did or didn't recognize companies which would go bankrupt in the following years. Since we had observations from the period 2007-2012, we were able to analyze the predictive ability of the respective models five years in advance (for 2012), four years in advance (for 2011) and three years in advance (for 2010).

\section{Results and Discussion}

In the following table, we summarize the critical values of the above-mentioned prediction models. A model is supposed to detect forthcoming bankruptcy if the resulting value lies within the below-defined intervals.

Table 6 Critical values of distress prediction models

\begin{tabular}{|c|c|c|c|c|c|}
\hline Model & $\begin{array}{c}\text { Quick- } \\
\text { test }\end{array}$ & Taffler & IN99 & IN05 & $\begin{array}{c}\text { Altman } \\
\text { Z'-score }\end{array}$ \\
\hline $\begin{array}{c}\text { Critical } \\
\text { value }\end{array}$ & $<1$ & $<0.2$ & $<0.648$ & $<0.9$ & $<1.23$ \\
\hline
\end{tabular}

The results are summarized in tables 6, 7 and 8 .

Table 6 Prediction of business failures for 2012 - five-year predictive ability

\begin{tabular}{|c|c|c|c|c|c|}
\hline \multirow{2}{*}{$\begin{array}{c}\text { Years in } \\
\text { advance }\end{array}$} & \multicolumn{4}{|c|}{ Percentage of correct predictions } \\
\cline { 2 - 6 } & $\begin{array}{c}\text { Quick- } \\
\text { test }\end{array}$ & Taffler & IN99 & IN05 & $\begin{array}{c}\text { Altman } \\
\text { Z'-score }\end{array}$ \\
\hline $\mathbf{1}$ & $23.7 \%$ & $13.7 \%$ & $38.2 \%$ & $50.9 \%$ & $44.3 \%$ \\
\hline $\mathbf{2}$ & $23.4 \%$ & $11.7 \%$ & $39.8 \%$ & $49.5 \%$ & $48.8 \%$ \\
\hline $\mathbf{3}$ & $27.6 \%$ & $15.7 \%$ & $44.9 \%$ & $52.3 \%$ & $42.9 \%$ \\
\hline $\mathbf{4}$ & $24.0 \%$ & $12.0 \%$ & $33.6 \%$ & $46.8 \%$ & $37.9 \%$ \\
\hline $\mathbf{5}$ & $15.5 \%$ & $7.8 \%$ & $28.4 \%$ & $45.6 \%$ & $37.4 \%$ \\
\hline
\end{tabular}

The five-year predictive ability for 2012 of individual models varies considerably. It is clear that IN05 index of credibility provided the best results in all previous five years, followed by the Altman Z'score and IN99 index. The Taffler and Quicktest models had the worst predictive ability. An interesting observation is that there is no significant decrease of predictive ability of most models over the course of time.

Table 7 Prediction of business failures for 2011 four-year predictive ability

\begin{tabular}{|c|c|c|c|c|c|}
\hline \multirow{2}{*}{$\begin{array}{c}\text { Years in } \\
\text { advance }\end{array}$} & \multicolumn{4}{|c|}{ Percentage of correct predictions } \\
\cline { 2 - 6 } & $\begin{array}{c}\text { Quick- } \\
\text { test }\end{array}$ & Taffler & IN99 & IN05 & $\begin{array}{c}\text { Altman } \\
\text { Z'-score }\end{array}$ \\
\hline $\mathbf{1}$ & $23.5 \%$ & $13.6 \%$ & $38.6 \%$ & $50.9 \%$ & $44.7 \%$ \\
\hline $\mathbf{2}$ & $27.3 \%$ & $15.6 \%$ & $45.3 \%$ & $51.8 \%$ & $43.3 \%$ \\
\hline $\mathbf{3}$ & $23.8 \%$ & $11.9 \%$ & $34.1 \%$ & $46.8 \%$ & $38.4 \%$ \\
\hline $\mathbf{4}$ & $15.5 \%$ & $7.8 \%$ & $28.4 \%$ & $45.6 \%$ & $37.4 \%$ \\
\hline
\end{tabular}

The four-year predictive ability for 2011 of individual models also varies substantially. In this case, IN05 
provided the best results again, followed by Altman Z'-score and IN99 index. Again, the Taffler and Quicktest models had the worst predictive ability.

Table 8 Prediction of business failures for 2010 three-year predictive ability

\begin{tabular}{|c|c|c|c|c|c|}
\hline \multirow{2}{*}{$\begin{array}{c}\text { Years in } \\
\text { advance }\end{array}$} & \multicolumn{4}{|c|}{ Percentage of correct predictions } \\
\cline { 2 - 6 } & $\begin{array}{c}\text { Quick- } \\
\text { test }\end{array}$ & Taffler & IN99 & IN05 & $\begin{array}{c}\text { Altman } \\
\text { Z'-score }\end{array}$ \\
\hline $\mathbf{1}$ & $26.9 \%$ & $14.5 \%$ & $43.5 \%$ & $56.1 \%$ & $44.0 \%$ \\
\hline $\mathbf{2}$ & $28.0 \%$ & $12.7 \%$ & $34.4 \%$ & $50.6 \%$ & $38.0 \%$ \\
\hline $\mathbf{3}$ & $14.8 \%$ & $8.9 \%$ & $29.0 \%$ & $44.3 \%$ & $35.9 \%$ \\
\hline
\end{tabular}

The three-year predictive ability for 2010 provides similar results. Both credibility indexes together with the Altman Z'-score provided the best results.

The results show that the IN05 model had the best overall accuracy for companies which went bankrupt in 2012 and 2011 and provided acceptable outcomes even five years prior to going bankrupt. Among other models which had the highest accuracy, we can cite the IN99 model which is another credibility index and Altman Z'-score. These models seem to perform well in the Czech conditions. The Taffler model seems to provide the worst outcomes, which is consistent with the findings of Maňasová (2007). The results may be explained by the fact that credibility indexes have been designed especially for the Czech environment and should therefore best reflect the particularities of it.

\section{Managerial Implications}

Managers and analysts often rely on popular bankruptcy models because of the fact that they are easily measurable and their interpretation is straightforward. However, the predictive ability of these models, in particular Taffler and Quicktest, seems to be limited. We can confirm the usefulness of the credibility indexes (IN99 and IN05) in predicting a company's distress in the Czech environment, which is consistent with the findings of most authors, as well as the Altman Z'-score model. Moreover, it seems that the models do not significantly lose their predictive ability over the course of time; even five years prior to going bankrupt, a model may provide a useful warning on the possible financial distress of a company. However, all the analyzed modes are based on empirical analysis of historical data, without taking into account the present circumstances. Also, such models share the limitations of the accounting model, including the accounting concepts on which they are based.

\section{References}

Agarwal, V., Taffler, R. J. (2007). Twenty-five years of the Taffler z-score model: Does it really have predictive ability? Accounting and Business Research, 37 (4): 285-300.

Altman, E. I. (1968). Financial Ratios, Discriminant Analysis and the Prediction of Corporate Bankruptcy. Journal of Finance, 23 (4): 589-603.

Altman, E. I. (2012). Predicting Financial Distress of Companies: Revisiting the Z-Score and ZETA (R) Models, in Handbook of Research in Empirical Finance, ed. Elgar, E., Brooks, C., Cheltenham: Edward Elgar, 7-36.

Č́mská, D. (2012). National View of Bankruptcy Models, in International Days of Statistics and Economics, ed. Pavelka, T., Löster, T., Slaný : Melandrium, 268-278.

Collins, R. A. (1980). An empirical comparison of bankruptcy prediction models. Financial Management, 9 (2): 52-57.

Kralicek, P. (1991). Grundlagen der Finanzwirtschaft: Bilanzen, Gewinn- und Verlustrechnung, Cashflow. Kalkulationsgrundlagen, Fruehwarnsysteme, Finanzplannung. Wien: Ueberrauter, 1991.

Krause, J. (2013). Risk management in companies and the importance of selected measures for overcoming the crisis. WSEAS Transactions on Business and Economics, 10(3): 133-141.

Maňasová, Z. (2007). Úpadky podniků v České republice a možnosti jejich včasné predikce. Disertation thesis. Prague: University of Economics.

Neumaierová, I, Neumaier, I. (2014). INFA Performance Indicator Diagnostic System. Central European Business Review, 3 (1): 35-41.

Smrčka, L., Schönfeld, J. (2014). Several conclusions from research of insolvency cases in the Czech Republic. Central European Business Review, 3 (1): 13-19.

Taffler R. J., Tisshaw, H. (1977). Going, going, gone - four factors which predict. Accountancy, 88: 50-54.

Tyll, L. (2011). Outsourcing v krizi. Finanční ř́zení \& controlling $v$ praxi, 2(12): 32-35.

Wang, Y., Campbell, M. (2010). Do Bankruptcy Models Really Have Predictive Ability? Evidence using China Publicly Listed Companies. International Management Review, 6(2).

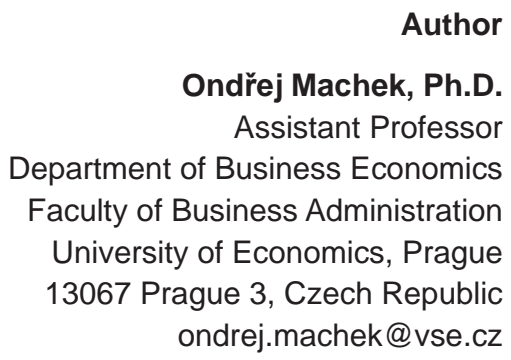

The paper is one of the outcomes of the research project VŠE IP300040 The crucial aspects of the competitiveness of enterprises and national economies in the global economic system. 